\title{
The Economic Development Model in Supporting The Economy of Pariaman Regional Area
}

\author{
Bakaruddin', Usnimar², Zulkifli' ${ }^{3}$, Hasdi Aimon ${ }^{4}$ \\ ${ }^{1}$ Faculty of Economics, Universitas Negeri Padang, Padang Indonesia, \\ $\square$ (e-mail) bakaruddin@umri.ac.id \\ ${ }^{2}$ Faculty of Economics, Universitas Negeri Padang, Padang Indonesia, \\ $\varangle$ (e-mail) usnimarS3@gmail.com \\ ${ }^{3}$ Faculty of Economics, Universitas Negeri Padang, Padang Indonesia, \\ $\triangle$ (e-mail) zulkifli0864@gmail.com \\ ${ }^{4}$ Dept. of Economics, Faculty of Economics, Universitas Negeri Padang, Padang Indonesia, \\ $\triangle$ (e-mail) hasdiaimon1955@gmail.com
}

\begin{abstract}
Along with the development and economic growth, the role of tourism today is increasing as a new sector of foreign exchange contributors that is large enough to improve the welfare of the community. Indonesia as one of the countries that have a wealth of natural and cultural extraordinary, also enjoy this benefit. However, tourism is also often regarded as one of the biggest contributors to damage to the environment and society, especially through the development of supporting infrastructure. Pariaman, as one of tourism destination cities in West Sumatra, faces symptoms of shifted cultural values as well as social and environmental wisdom. Ecotourism, then viewed as one alternative policy that can be used as a solution to this problem. Using a qualitative approach, this study was conducted with the aim of formulating a sustainable ecotourism model based on cultural values, social and environmental wisdom that will support the success of tourism development in Pariaman. With the formulation of a policy model, it is expected the model can serve as a guide for the government in developing national policies in the field of sustainable tourism in particular and supporting economic independence in the region.
\end{abstract}

Keywords: ecotourism, economic model, sustainable, and tourism

\section{Introduction}

Technological progress and tourism have been going hand in hand for years (Sheldon, 1997; Poon, 1993). Since the 1980s, Information Communication Technologies (ICTs) have been transforming tourism globally. Developments in ICTs have undoubtedly changed both business practices and strategies as well as industry structures (Porter, 2001). The establishment of the Computer Reservations Systems (CRSs) in the 1970s and Global Distribution Systems (GDSs) in the late 1980s, followed by the development of the Internet in the late 1990s, have transformed the best operational and strategic practices in the industry dramatically (Buhalis, 2003; O'Connor, \& Murphy, 2004).

Tourism is positioned as one of the leading sectors in Indonesia's national development. Currently and in the future, tourism is expected to provide the greatest contribution to the increase of foreign exchange in the government's efforts to realize the welfare and prosperity of the people. One of the efforts made by the tourism sector is to continue to improve its performance by strengthening existing networks and increasing the competitiveness of Indonesian tourism business (Astuti, 2008). While providing great benefits for the development of the world's welfare, tourism development is also often cited as one of the major sources of environmental degradation, when the development of tourism requires the provision of infrastructure that must destroy nature as mentioned in the 1996 World Tourism Organization report. cases in some areas, resort and hotel developments must destroy beaches, seas, forests and other pre-existing and growing ecosystems. Tourist crowds also have an 
impact on animal behavior change, which is demonstrated by aggressive behavior that is often dangerous (Putra, 2006).

Viewed from various reports, the growing tourism in Indonesia also leaves a lot of worries, when perceived tourism development is now more dominated by economic and aesthetic values related to industrial development, compared to the development of cultural ethical values, social and environmental wisdom of the community. Instead the government has not put the benchmark of tourism success from the welfare side participation and satisfaction. people directly in direct contact with tourists. Local people who are supposed to be the main subjects in tourism management are in fact the subject of sufferers governed by various forms of restraint in the name of visitor satisfaction. Given the essence of tourism itself is broader than just an economic indicator, it is appropriate to have an interpretation of tourism so that it is not monopolized only on economic relations. With this interpretation, tourism will be more dynamic with the characteristics of growth, globalization, integration, the dialogue between cultures, multidisciplinary, sensitivity and recuperation which is the core of the Global Code of Ethics for Tourism principle (Teguh, 2008).

Sustainable tourism development, as mentioned in the Sustainable Tourism Charter (1995) is a development that can be ecologically supported as well as economically feasible, as well as ethically and socially equitable to the community. That is, sustainable development is an integrated and organized effort to develop quality of life by means of manage the continuous provision, development, utilization and maintenance of resources. How to make revenues reentry so that nature conservation can self-finance is at the core of this new branch of green economics of sustainable development (Western, 1999). Ecotourism offers unity of travel value that is integrated between the balance of enjoying the beauty of nature and the effort to preserve it. This ecotourism can play an active role in providing solutions in solving problems that may occur in the development of tourism areas. The main focus of the ecotourism model development is based on the basic potential of tourism where nature and cultural preservation is put forward (Dirawan, 2008).

As one of the main tourist destinations in Indonesia, the city of Pariaman of Province West Sumatra has many basic factors and centered on Minangkabau culture that is in harmony with the history and culture Tabuik in Pariaman is the local wisdom and noble values of the nation's culture as well as the increase of tourism activities carried out by creating innovations that are based on cultural tours, historic building tours, educational tours, convection tours and shopping.

Unfortunately, along with the modernization and economic globalization that caused the increasing pressure of community life, as well as the pressure from the increase of tourism industry that already exist. Some negative conditions have begun to be felt in Pariaman, both in terms of changes in cultural values. From the research of Good Governance on Water Resources Management (GGWRM) EU, garbage collected through garbage bins is then transported to a temporary dump and so on to landfill.

\section{Drainage Network and community-based}

This system has been planned in several locations in Pariaman but until now has not been fully realized. Increasing the point of the location of garbage disposal to the river of course illustrates the increasing public indifference to cleanliness and smooth function of the river itself. Tourism is a multidimensional concept like the understanding of tourists. It is inevitable that some sense of tourism is used by practitioners with different goals and perspectives in accordance with the objectives to be achieved. For example, some experts define that tourism comprises the ideas and opinions of the people who are about to go on their trips, about where to go and what to do, about how to relate to other tourists, local and service personnel. And it is all the behavioral manifestations of these ideas and opinions (Pitana \& Diarta, 2009). The activities of persons traveling to and staying in places outside their usual environment for not more than one consecutive year for leisure, business and other purposes (Pitana \& Diarta, 2009). 
According to Richter and Richter, almost universally the governments of the world receive tourism something positive so that most tourism policies are made to expand the tourism industry (Hermawan, 2008). He further states that government agencies at all levels from international to small towns gradually play a more active role in the use of tourism as a tool of development Relations with culture, tourism itself has many goals and one of them is culture. Tourists generally aim for a vacation, take time to get pleasure. That is why for sunbathing and swimming nations, the beautiful coastal area is a popular tourist destination. Sometimes it also adds to the typical spa or massage opportunities, or styling the hair into small braids. Attractions of culinary and art can also be an added value for a tourist area. But the excesses of freedom of interaction between guests or between guests and the host can also lead to prostitution and drug trafficking.

\section{Sustainable Tourism}

The definition of tourism sustainability is closely linked to current tourism needs that should not sacrifice and diminish the rights and needs of future generations. The issue of conservation of natural resources and the environment is contained in the agreement of the nations of the world at the Earth Summit organized by UNCED (United Nation Conference on Environment and Development) better known as the Rio Summit. The various agreements in the 1992 Rio Summit were evaluated at the Johannesburg conference in 2002 which underscores the implementation of sustainable development in all fields. The Earth Summit produces 5 (five) points of agreement that are closely linked to the conservation of natural resources and the environment that includes: the Rio Declaration, Climate Change Conservation, Biodiversity Conservation, Forestry Principles and schedule. The principles and targets of the charter are:

a) Tourism development must be based on sustainability criteria that can be ecologically supported for a long time, economically, ethically and socially equitable to the local community;

b) Tourism should contribute to sustainable development and integrate with the natural, cultural and human environment;

c) Governments and competent authorities with the participation of non-governmental organizations with local communities should take action to integrate tourism planning as a contribution to sustainable development;

d) Governments and multilateral organizations should prioritize and strengthen direct, direct or direct assistance to tourism projects that contribute to the improvement of environmental quality;

e) Spaces with current and future vulnerable environments and cultures should be given special priority in terms of technical cooperation and financial assistance for sustainable tourism development. Promotion or support of alternative forms of tourism in accordance with the principles of sustainable development;

f) Governments should support and participate in the creation of networks for research, dissemination of information and knowledge transfer on tourism and sustainable tourism technologies;

g) The establishment of a sustainable tourism policy requires the support and sustainable tourism management system, feasibility studies for sector transformation and implementation of pilot projects and the development of international cooperation programs.

Definition of ecotourism, as outlined by the Green Tourism Association, is a tourism development that has four pillars or attributes namely;

a) Environmental responsibility; contains a definition of protection, conservation or expansion of natural resources and the physical environment to ensure long-term life and ecosystem sustainability, such as wet end natural attractions that will produce a sustainable ecosystem concept of rhinoceroses;

b) Local economic vitality; encouraging the growth and development of local economies, businesses and communities to ensure strength economic and sustainability (e.g. sustainability) such as the construction of tourist sites will usually be followed by the rise of local economic activities; 
c) Cultural sensitivity; encouraging respect and appreciation of cultural customs and diversity to ensure the viability of a good local culture such as through cultural tourism, people will recognize the culture of the region or other country and generate respect for the cultural treasures;

d) Experiential richness; creating attractions that can enrich and enhance a more satisfying experience, through active participation in personal understanding and involvement with nature, people, places and / or culture (Yoeti, 2006).

The type of research conducted is Causal Comparative Research (Causal Comparative Research) which is a type of research that aims to find possible causal relationships by observing the consequences that are now there and trying to find possible causes of data collected. Causal relationship to be analyzed is the change of cultural values, social, environment as the cause of the impact for tourism activities in the form of symptoms of unsustainable tourism development in Pariaman, West Sumatra Province as a result. The place chosen as a research location is Pariaman of West Sumatra Province with respondents of various cultural actors, community leaders, tourists and parties related to sustainable tourism development activities, to get a picture of cultural values, social and environmental wisdom that support the development sustainable tourism in Pariaman.

As a sample of the study selected 3 tourist village is Pasir tourism village Gandoriah Beach, Lohong Village tourist beach Kata and Karang Aur village taurist beach Cermin The result of the interview is used as one of assessment base to evaluate and review the implementation of sustainable tourism in Pariaman as well as confirmation to tourists through a structured questionnaire instrument to get a picture of their perceptions related to the implementation of ecotourism in Pariaman as well as the willingness to participate in the ecotourism development. The sampling technique used in this study is the method of accidental sampling (non-probability sampling).

The method chosen by considering the size factor of the population or sample is unknown because the researcher does not know anyone who will be the visitor of tourist location because of the nature of non-probability sampling, hence this research cannot generalize a general conclusion Data collection technique is done by using in-depth interview method with various research informants that will be analyzed by using content analysis method to get an overview of social, cultural and environmental change process in Pariaman related to sustainable tourism development. The research is largely based on a qualitative approach to describe the tourism development process in Pariaman, West Sumatra. Qualitative approach is also done for the purpose of exploring information from all parties responsible in carrying out tourism activities.

The variables that become the main indicator in this research are the variables of cultural values, social and environmental wisdom in Pariaman of West Sumatera Province, which will become one of the analysis materials based on theory, until it can be arranged into a model of sustainable ecotourism development.

Based on the above phenomenon, some problems can be formulated as follows.

1. How is Ecotourism criteria with aspects of sustainable development in Pariaman?

2. How is the Sustainable Development model implemented in Pariaman City?

\section{Results and Discussion}

In accordance with the mandate of the Regional Medium Term Development Plan (RPJMD) of Pariaman, which states that: the vision of Pariaman is "the clean, peaceful and beautiful Pariaman for tourism." The mission of Pariaman is to achieve that vision it should be spelled out in a mission that includes:

1. Create an area zone that is regular, functional and aesthetic;

2. Improving the quality and quantity of sanitation infrastructure and facilities, especially in tourist areas; 
3. Increasing public participation and private participation in the provision and management of sanitation;

4. Increase the institutional capacity of government, private and community in sanitation management;

5. Improve regulation for sanitation management;

6. Increasing public awareness of clean and healthy living culture;

7. Improving the quality of a healthy and clean environment through the development of clean water facilities, waste water, drainage and garbage; and

8. Improving management system, operational and public service of sustainable sanitation sector.

This culture is also an aspect of the main advantages of tourism development in the city of Pariaman compared with tourism in other areas. The pattern of sustainable development, in essence must be based on the implementation of the fulfillment of three key aspects of ecological sustainability, social sustainability and economic sustainability. While a tourist area is categorized as ecotourism, in accordance with the criteria of Green Tourism Organization, the tourist area must meet environmental responsibility criteria, local economic vitality, cultural sensitivity, and experiential richness. Basically, the development of eco-tourism pillars based on the Green Tourism Organization can simultaneously answer the problems of sustainable development. The ecological sustainability aspect can be answered with the pillars of environmental responsibilities, then the pillars of local economic vitality, cultural sensitivity and experiential richness are the answers to social development objectives. More details of local economic vitality pillars also answer the problems of economic development. A direct comparison between ecotourism criteria and aspects of sustainable development can be observed in the figure below:

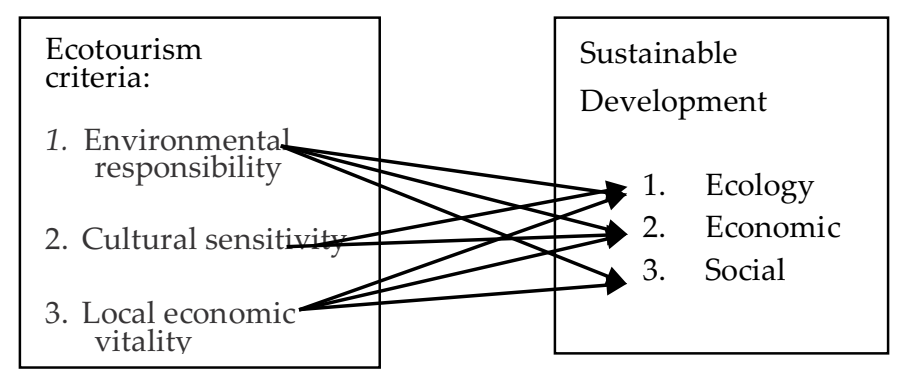

Figure 1 A comparison between ecotourism and sustainable development criteria

Pasir village is a village located in the southern part of Pariaman region, precisely in Center Pariaman District, City of Pariaman. Pariaman area is around $66.13 \mathrm{~km}^{2}$ with the number of villages and villages as many as 71 units with a population of 85,485 thousand (DCKS data, 2017). Based on UU RI No. 12 Year 2002 dated 10 April 2002 on Management Model of Tourism with development of eco-tourism pillars based on Green Tourism Organization can at once answer the problem of sustainable development. The vision developed in Desa Kelurahan Pasir is the vision of the realization of independent tourist village, the increasing of community income and the managers for the common prosperity. While the missions developed include; the establishment of supporting facilities and infrastructure, optimizing natural resources and human resources, strengthening the management institutions, promoting the promotion and service of guests. The basic idea of the establishment of Pasir village is the belief that the potentials of Pasir village in particular and Pariaman in general can be developed. The programs must be beneficial to the community and managers, get support from the community and government, package potentials, rights and obligations communities and managers are clear, and certainly have a market share. From the analysis, it turns out that all stakeholders involved in higher education, homestay owners, village communities, local government and visitors have a significant role in forming a chain of successful implementation a tourism village. 
Pariaman has a variety of tourism attractions such as Gandoriah Beach, Kata Beach, Coastal Mirror, Turtle Breeding located in Mangguang village, North Pariaman district. Based on the analysis of various forms and types of tourism management in the city of Pariaman today, this research considers that the type of community based tourism management, in the form of tourism village, is a type of tourism management that can be recommended as a Sustainable Tourism Development Model in Pariaman, as a form of implementation of the concept of ecotourism. Hopefully, the model can be used as a rationale in the preparation of tourism development policy in Pariaman in particular and national in general. From various in-depth analysis results and direct field visits to several Village / Tourism Village that exist and grow in West Sumatera Province, Tourism Village that really meet the aspects and criteria of ecotourism that will produce the concept of sustainable tourism in Pariaman is Pasir village.

The existence of the concept of temporary residence time together with the community is a form of implementation of local economic strengthening efforts independently in accordance with local economic vitality pillars; (2) During the settlement together with the community, tourists will live side by side normally with the activities of the villagers, so that tourists will be able to feel directly how the activities of villagers running every day as well as learn the concept of social kinship, cultural wealth and environmental wisdom owned by the community in each of the Tourism Villages as an implementation of the pillars of environmental responsibility and cultural sensitivity; (3) Each Tourism Village also offers various forms of performances to tourists who describe the cultural wealth, social wisdom and wisdom of the Tourism Village environment. The show's activities in addition to providing income aspect for the community as well as efforts to preserve cultural values, social and environmental wisdom which describes the progress of pillars environmental responsibility, cultural sensitivity, local economic vitality and experiential richness; (4) In each of the Tourism Villages, tourism activities are not their main occupation. Basically, the people in each tourism village already have the status of main job, the majority as fishermen, some become traders, some are self-employed, some are tourist guides in the city, builders, tire repairers and all other types of work.

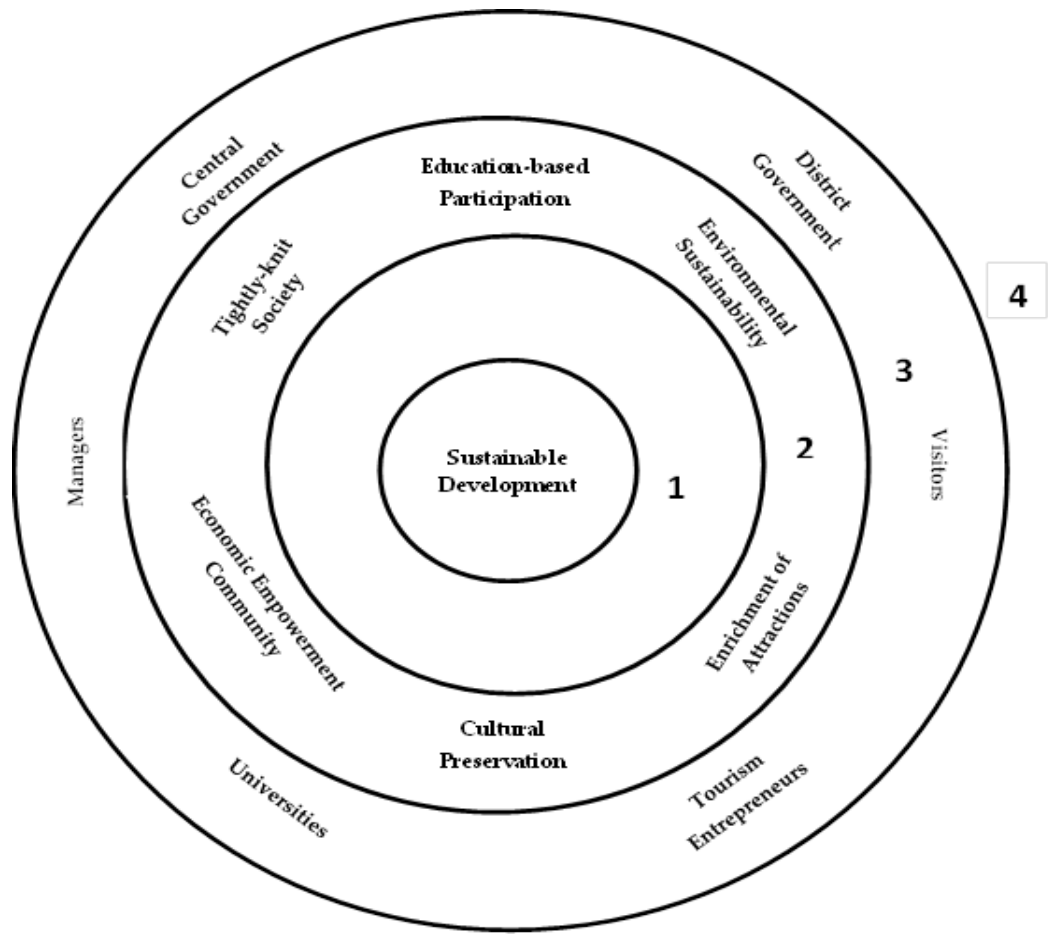

Figure 2 The model of sustainable ecotourism development

Communities closer, more respectful, more respectful, prosperous together are the indicators that they think are more important than mere economic indicators in terms of profit levels, high 
occupancy rates, the high competitiveness of their villages, because if three tourism village sample is excess visitors who stay, will voluntarily be given to the neighboring village tour, or for example easily the group of visitors can negotiate a deal price stay at the community if the group of visitors have budget constraints. Based on the input of type of community-based tourism management in the form of selected Tourism Village, the recommendation of sustainable tourism management policy in Pariaman in particular and West Sumatera and national in general can be arranged in a Model of Sustainable Tourism Development as presented in Figure 2.

This model is expected to be applied as a policy for sustainable tourism development not only in Yogyakarta, but in all regions in Indonesia especially in the main tourist destination areas. Sustainable Ecotourism Development Model will be arranged based on the classification of four elements. First, making the issue of sustainable development as the primary vision and objective of the pattern of tourism development and management, called the Main Element. Second, communitybased tourism as the Tourism Product Element. Third, pillars of environmental conservation, cultural preservation, enrichment of attractions, participation-based education, community relations, and economic empowerment of local communities as Criteria Elements. Fourth, supported entirely by all stakeholders and stakeholders of the community, visitors, managers, universities, central government, local government and tourism entrepreneurs as Element Supporters.

\section{Conclusions}

The form and type of community-based tourism management in the form of tourism village is a form of tourism that can be a Model of Sustainable Ecotourism Development in Pariaman specifically and nationally in general. Sustainable Ecotourism Development Model will be organized based on the classification of four elements as follows. First, the issue of sustainable development as the vision and main objective of the pattern of tourism development and management, referred to as the Main Element. Second, a community-based tourism as a Pari-tourism product element. Third, having a pillar of environmental preservation, cultural preservation, enrichment of attractions, participationbased education, community closeness, and economic empowerment of local communities as Criteria Elements. Fourth, fully supported by all stakeholders and shareholders of the community, visitors, managers, colleges, central government, local government and tourism entrepreneurs as the Supporting Elements.

The results of this study may be of interest for local government. The model of sustainable ecotourism development consists of four main elements as the basic concept of tourism development in the region for the future. It is recommended for the central government to the establish this sustainable ecotourism development model.

\section{References}

Afri, L. (2005). The influence of tourism object of Borobudur temple against socio-economic behavior of traders in Borobudur temple tourism area of Magelang regency. Thesis. Bachelor of Pancasila and Citizenship Education. State University of Semarang.

Akiva, B., Moshe, \& Steven, R. L. (1985). Discrete Choice Analysis: Theory and Application to Travel Demand. Massachusetts: The MIT Press.

Anthony. (2004). Structured Theory for Social Analysis. Yogyakarta: Topprint.

Arianto, A. (2004). The effort of Pacitan Regency government in conserving culture of Cepotran (Case study of culture and tourism office of Pacitan). Thesis. Department of Governmental Science FISIP. Universitas Muhammadiyah Malang.

Baiquni, M. (2009). Learning from Install Recede Borobudur and Concept Development of Boro-kelur Tourism. Final Report. Faculty of Geography and Center for Tourism Studies. Gadjah Mada University.

Barika. (2009). Impact Assessment of Tourism Sector Development in Bengkulu City; Case Study of Long Beach Beach Area and Padri Site. Thesis. Graduate School. Institut Pertanian Bogor. 
Baskoro, B. R. A., \& Cecep, R. (2008). Building community-based tourism town: A theoretical study. Journal of Indonesian Tourism Ministry of Culture and Tourism of Indonesia, 3(1), 5-7.

Binarwan, R. (2008). Development of community-based tourism in tourism object Ciater West Java. Journal of Indonesian Tourism Ministry of Culture and Tourism of Indonesia, 3(4), 3-5.

Bukhari, Z. (2005). Strategy for Developing Superior Malay Culture in Bengkalis Regency. Final Project. Study Program of Regional Development Management of Graduate School. Institut Pertanian Bogor.

Buhalis, D. (2003). eTourism: Information Technology for Strategic Tourism Management. New York: Pearson.

Butler, R. W. (1975). Tourism as an Agent of Social Change, Tourism as a Factor in National and Regional Development. Occasional Paper for Peterborough Ontario, Department of Geography. Trent University.

Chaerun, N. M. (2008). The Influence of Tourism Activity on Tourism Resource Sustainability on PAI Tourism Object, District Tegal. Final Project. Department of Regional and City Planning.

Creswell, J.W. (2003). Sage Publication Inc.'s Research Design Qualitative, Quantitative and Mixed Methods Approaches. United Kingdom: Sage Publication.

Damanik, J. \& Helmut, F. W. (2006). Ecotourism Planning; From Theory to Applications. Center Cooperation UGM \& Publisher Tourism Study. Yogyakarta: Andi.

Dirawan, G. D, (2006). Ecotourism development strategy (Case study of Mampie Lampoko Wildlife Sanctuary). Journal of Indonesian Tourism.

Freeman, A. M. (1993). The Measurement of Environmental and Resurrection Values: Theory and Methods. Washington, D.C.

Hadi, A. W. M. (2008). Takdir Alisyahbana and Cultural Thought. Journal of Paradaban Jurnal Rasmi Pusat Dialog Paradaban, 1.

Himooned, T. (2007). Opportunities and constraints of local participation in ecotourism: Case study of Kasanka National Park (KNP) Zambia. Thesis in Development Studies. Norwegian University of Science and Technology

Iamtrakul, P. K. T \& Kazunori, H. (2005). Public park valuation using travel cost method. Proceedings of the Eastern Asia Society for Transportation Studies, 5, 1249-1264.

Irawati, E. P. \& Roni. (2009). Study of Planning of Integrated Coastal Tourism Area Management of Padang (Case Study of Padang-Padang Beach Area Management). DIPA. Andalas University.

Ismanto, Hasanudin. (2006). Tourism conflict in Padang Pariaman. Draft Article Scientific Research Young Lecturer. Faculty of Literature, Department of Regional Literature. Andalas University.

Karomah, P. M. \& Kapti, A. (2007). community readiness code to increase living skills by utilizing industrial waste as souvenirs in Yogyakarta. Journal Research Bappeda Kota Yogyakarta, 2.

O'Connor, P., \& Murphy. J. (2004). Research on information technology in the hospitality industry. International Journal of Hospitality Management, 23(5), 473-484.

Poon, A. (1993). Tourism, Technology and Competitive Strategies. Oxford: CAB International.

Porter, M. (1979). How competitive forces shape strategy. Harvard Business Review, 57(2), 137-145.

Sheldon, P. (1997). Tourism Information Technologies. Oxford: CAB International.

Widodo. (2008). Identification of Wediombo potential as eco-tourism area in Gunung-kidul Regency, Yogyakarta Special Region. Journal of Indonesian Tourism, Ministry of Culture and Tourism of Indonesia, 3(1). 